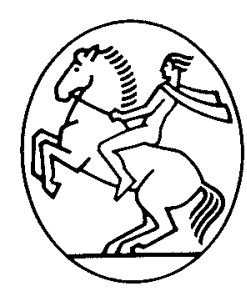


H. Resch and E. Beck (eds.)

\section{Arthroscopy of the Shoulder}

Diagnosis and Therapy

Translated from the German by M.-L. Antoft and B. Marschall

Springer-Verlag Wien New York 
Dr. Herbert Resch

Dr. Emil Beck

Universitätsklinik für Unfallchirurgie

Innsbruck, Austria

This work is subject to copyright.

All rights are reserved, whether the whole or part of the material is concerned, specifically those of translation, reprinting, re-use of illustrations, broadcasting, reproduction by photocopying machine or similar means, and storage in data banks.

Product Liability: The publisher can give no guarantee for information about drug dosage and application thereof contained in this book. In every individual case the respective user must check its accuracy by consulting other pharmaceutical literature.

The use of registered names, trademarks, etc. in this publication does not imply, even in the absence of a specific statement, that such names are exempt from the relevant protective laws and regulations and therefore free for general use.

(C) 1992 by Springer-Verlag/Wien

Softcover reprint of the hardcover 1st edition 1992

Printed on acid-free paper

With 125 Figures (63 in color)

ISBN-13:978-3-7091-9205-4

e-ISBN-13:978-3-7091-9203-0

DOI: $10.1007 / 978-3-7091-9203-0$ 


\section{Preface}

In the last few years arthroscopy has been firmly established as an investigative and therapeutic modality with regard to the knee and more recently to the shoulder joint. The establishment of a clinical diagnosis in the shoulder joint can be a difficult problem, as the site of the symptoms only very rarely coincides with the area of the actual lesion. Diagnostic arthroscopy together with other imaging techniques has greatly contributed to the assignment of symptoms to particular lesions. Direct visualization of the intraarticular structures provides clear and precise information in both normal and pathological conditions. Visual exploration on the intraarticular structures allows arthroscopy to be used as a means of diagnosis also in the soft tissue layer of the soulder joint. The thick soft tissue layer surrounding the shoulder joint, in particular, presents a challenge to avoid open surgery, as arthroscopic surgery shortens the postoperative rehabilitation time. This is why a variety of therapeutic techniques in the field of arthroscopic surgery have been and are still being intensively researched. Several methods have already become routine. Bankart refixation techniques as well as techniques for arthroscopic acromioplasty are two examples.

This brings us to mention the excellent cooperation provided by members of the Institute of Anatomy of the University of Innsbruck. We would also like to thank the head of the institute, Prof. Dr. W. Platzer, for his generous support in founding an arthroscopic laboratory for research in his department. Some of the already existing arthroscopic surgical techniques were improved and new ones developed in this laboratory.

The primary objective of this book is to provide comprehensive information on the latest developments in diagnostic and therapeutic arthroscopy. We have tried to include as much practical information as possible, much of it gained from trial and error experience in our department, but also gleaned from published reports and personal communications with other surgeons.

A wide range of illustrations hopefully assists comprehension of the text and, in particular, illustrates the individual operative steps. Furthermore, we considered it important to emphasize the indications for arthroscopic surgery and the preoperative assessment has been given considerable attention.

The manuscript was translated by Marie-Louise Antoft and Brigitte Marschall. The editors gratefully acknowledge the assistance by Dr. Roger Butorac, F.R.A.C.S., Salt Lake City, Utah in the editing of this volume and express their appreciation to Dr. Robert A. Balyk, F.R.C.S., Edmonton, Alberta and Dr. Tim Briggs, London for reviewing the translation.

Innsbruck, May 1992

H. Resch and E. Beck 


\section{Contents}

Anatomy of the shoulder joint (H. Maurer, M. Lener) 1

Anesthesia for shoulder surgery (I. Braito, R. Haberler, H. Resch) 17

Preparation for arthroscopy (K. Golser, H. Resch, M. Lener) 23

Diagnostic arthroscopy (H. Thöni, H. Resch, G. Sperner) 41

Diagnostic bursoscopy (G. Sperner, H. Resch, K. Golser) 65

Arthroscopic Bankart refixation techniques

1. Arthroscopic Bankart suture repair (W. Glötzer, H. Resch, H. Thöni) 81

2. Arthroscopic three-point Bankart suture repair (P. Habermeyer, E. Wiedemann) 90

3. Arthroscopic screw fixation techniques (H. Resch, K. Golser, A. Kathrein) 99

4. Arthroscopic Bankart refixation with absorbable staples (H. Resch, G. Sperner, K. Golser)

5. Evaluation of the individual arthroscopic Bankart refixation techniques and our own method (H. Resch)

Arthroscopic operations in the subacromial space

1. Arthroscopic subacromial decompression (H. Resch, G. Sperner, H. Thöni)

2. Arthroscopic subacromial calcium removal (H. Resch, G. Sperner, K. Golser) 141

3. Arthroscopic resection of the lateral end of the clavicle

(H. Resch, H. Thöni, R. Butorac) 


\section{List of contributors}

M. Lener

H. Maurer

Institut für Anatomie der Universität Innsbruck, Innsbruck, Austria

I. Braito

R. Habeler

Universitätsklinik für Anästhesie und Intensivmedizin, Innsbruck, Austria

W. Glötzer

K. Golser

A. Kathrein

H. Resch

G. Sperner

H. Thöni

Universitätsklinik für Unfallchirurgie, Innsbruck, Austria

P. Habermeyer

E. Wiedemann

Klinikum Innenstadt, Ludwig-Maximilians-Universität, Munich,

Federal Republic of Germany

R. Butorac

Division of Orthopedics, University of Utah Medical Center, Salt Lake City, Utah, USA

Drawings by C. Konzett, Dornbirn, Austria und S. Mills, Munich,

Federal Republic of Germany 